\title{
Salonní próza Jana Liera v časopise Lumír v letech 1878-1880
}

\author{
Pavlína Dušková
}

\begin{abstract}
Salon Prose by Jan Lier in the Lumír Magazine in the Years 1878-1880

Jan Lier published prose with an obvious salon theme in the periodical Lumír. Elements of several literary styles simultaneously dominated the prose at the time. The Parnassian features (ornamental descriptions, uniqueness of gems) coexisted with elements of conventional entertaining literature, which was dominated by the romantic plot. Even the educated middle-class readers considered Lier's prose attractive.
\end{abstract}

\section{KEYWORDS}

Lumír; salon prose; conventional literature; romanticism; parnassianism; realism.

\section{KLÍčOVÁ SLOVA}

Lumír; salonní próza; konvenční literatura; romanismus; parnasismus; realismus.

Prozaik, fejetonista, divadelní a výtvarný kritik Jan Lier (1852-1917) je v české literatuře považován zejména za tvưrce železniční novely, která do poloviny 19. století nebyla v literatuře pěstována (ČERVINKA 1912-1913: 95). Lier však do literatury pronikl nejen prózou s železniční tematikou, ale také se salonním námětem. Lierovu prozaickou tvorbu ovlivnilo cestování, zejména pak Francie a její společenská, umělecká atmosféra s náhledem na umění a kulturu. ${ }^{1}$ Jan Lier

1) Spolek Svatobor poskytoval Lierovi na cesty do zahraničí finanční podporu 200-250 zlatých (ANONYMa 1888: 192-193, ANONYMb 1888: 2). 
byl aktivní i v české společenské sféře ${ }^{2}$ a byl jmenován mimořádným členem České akademie císaře Františka Josefa (ANONYM 1892: 3-4). V prozaické činnosti Lier slučoval motivy čistě „domácí s ovzduším cizokrajným - románským, čímž byl řazen mezi autory vyznávající západní literaturu“ (STREJČEK 1915: 73). Náměty pro prózu se salonní tematikou čerpal jak z českého maloměsta, tak z prostředí vyšších společenských kruhů. Lierova próza se vyznačovala milostnou zápletkou s dějovým napětím, výstižnou vnější charakteristikou postav a realistickou kresbou prostředí a dobové atmosféry. Zároveň byla založena na konvenčním milostném syžetu. Jan Lier byl tradičně spojován s poetikou lumírovců, „k níž ho pojil kult formy, láska k západu, který mu representovala Francie, a odpor všemu, co mu znamenalo čínskou zed' a malicherné předsudky. V celé jeho bytosti byla nechut proti utilitarismu a úcta k tradici“" (DYK 1916-1917: 375). Tíhl zejména k francouzské konvenční literatuře: ${ }^{3}$ „Bohatě vzdělán, odkojen zejména duchem i formou literatur západních, nadán skvělými prostředky formálními, postavil se velmi záhy jaksi v čelo našich essayistů a feuilletonních causeurů ponerudovského pokolení [...] Dávno před V. Hladíkem obdivoval se s Bohumilem Havlasou eleganci a živému kouzlu francouzské novely a snil o zkulturnění, zevropštění českého románu“" (SEKANINA 1917: 520).

\section{Lierova salonní próza v časopise Lumír v letech $\mathbf{1 8 7 8 - 1 8 8 0}$}

Salonní literatura byla obecně spojována s klíčovou kulturní rolí společenských salonů v západoevropských zemích. Přestože provozování salonů v českých zemích bylo oproti západní Evropě pozadu, nalezneme v české literatuře autory, v jejichž dílech se objevovalo prostředí salonu či syžetové postupy typické pro salonní prózy. ${ }^{4}$ Salonní novela byla považována za prestižní útvar s bohatou tradicí ve „velkých“ literaturách, s nimiž se čeští autoři chtěli pochopitelně

2) Podporoval například spolek Minerva, jehož pomocí byla zřízena první česká dívčí stř̌ední škola. Mezi další podporovatele patřila Věnceslava Lužická (1832-1920), Karel Václav Rais (1859-1926) či Pavla Maternová (1858-1923) (LIER 1890: 3).

3) Inklinování k francouzským vzorům umění bylo patrné i v Lierově překladatelské činnosti. Jan Lier přeložil z francouzštiny celkem 25 dramatických her, pro Národní divadlo například hru Dámský krejčí (1889) od Georgea Feydeaua, Ustupte ženám (1900) Ch. M. Hennequina, Vyzvání k tanci (1901) A. Dumase st., Polosvět (1901) od A. Dumase ml. či Sardouovu Travičku (1909).

4) Výběrem Božena Němcová (Babička, 1855; Pohorská vesnice, 1856), Karolina Světlá (Dvojí probuzení, 1858; Sestry, 1859; Láska k básníkovi, 1860; Líbánky koketiny, 1860; Miláček lidu svého, 1882), Sofie Podlipská (Osud a nadání, 1872; Nalžovský, 1878), Ivan Klicpera (Jindra, 1876), Bohumil Havlasa (Tiché vody, 1876), ale i veselohry Jana Nerudy (Žena miluje srdnatost, 1860; Merenda nestř́dmých, 1860; Já to nejsem, 1863). 
měřit (MOCNÁ 1999: 148). V roce 1876 byla zřízena v Ottově knižnici edice Salonní bibliotéka s cílem vydávat české knihy určené do salonních knihoven vzdělanějších čtenářů středních vrstev: „Salon v tehdejší době znamenal nejlepší místnost v každé domácnosti, přepych a chloubu bytu. Stála v něm skř́ín nebo polička s knihami, z nichž ještě některá skvostně vázaná ležela na stole. Právě pro tento stůl a pro tuto skřín byla určena Ottova knižnice, aby z nich vytlačila cizí literaturu“ (ŠVEHLA 2002: 80). Anonymní recenzent ve Světozoru potvrzoval významný literární počin této edice: „Co dosud v ní bylo vydáno, necht' jsou to básně aneb novely, vše obsahem svým pozoruhodno a namnoze má vynikající význam literární; při tom pilně dbáno, aby obsah hověl vkusu vybranější společnosti a tak bibliotéka skutečně byla salonní“ (ANONYM 1879: 34). Nicméně i přesto, že salonní literatura zaujala v českém prostředí své určité místo, není v literárněvědné bohemistice dostatečně probádána. Problém je reflektován ve Slovníku literární teorie, ${ }^{5}$ dále pak v dílčích příspěvcích sborníku plzeňského sympozia Salony v české kultuře 19. století.

Samotné provozování společenských salonů bylo problematické, jelikož v české vlastenecké společnosti nebyly tak ideální podmínky jako v zahraničí. Jedna část společnosti salony obdivovala, druhá na ně pohlížela jako na prostředí nevhodné. Všechno salonní bylo pak logicky bud' obdivováno, nebo vnímáno s posměchem jako cizí, nevlastní rodícímu se „českému“ světu. Vytvářet český salon tak znamenalo popření všeho, co bylo v salonu vnímáno jako cizorodé a nevhodné pro českou společnost. Salony v českém literárním prostředí ironizovali již Karel Sabina (1813-1877) v díle Na poušti (1864) či Vítězslav Hálek (1835-1874) v básni A zavrou-li ti duše mělké z cyklu V př́rodě (1872-1874): „má pýcha nezrá po salonech, / leč v lidstva velké svatyni. / Tat' víra má: až bude čtena / ta suma lidské hodnoty, / dle tamtěch bude vypočtena, / ne dle hlav zpýchlé holoty" (HÁLEK 1912: 275). Gustav Pfleger-Moravský (1833-1875) satiricky popisoval společenské salony obsáhlými pasážemi ve veršovaném romá-

5) „Salónní literatura - obecně druh literární tvorby, libující si ve formální uhlazenosti a duchaplnosti a odtržené od života. Užívá se též konkrétně jako označení jedné z tendencí francouzské literatury 17. století, pěstované ve významných literárních salónech, v tomto smyslu je označení totožné s přesnějším termínem - preciózní literatura“ (KOVÁŘOVÁ 1984: 334-335). Dále pak: „Preciózní literatura - franc. précieux - vyumělkovaný, strojený. [...] Vznik a rozvoj p. 1. probíhal v intimní atmosféře aristokratických nebo měštanských patricijských salónů, kde se scházela vybraná společnost, aby diskutovala o událostech v zemi, u dvora i ve městě, ale také o novinkách literárních a divadelních, subtilních otázkách gramatiky apod. [...] Podněcovatelem p. l. jsou ženy - tzv. preciózky, milující duchaplnou konverzaci, lehkou ,causerii‘, v níž nechybějí poetické hádanky, kalambúry, vtipné slovní hříčky hlásající určité morální a sociální zásady, inspirované starým rytířským ideálem, oživeným prvky renesančního platonismu. [...] Literatura se tak obrací k ženskému publiku, jež ovlivňuje výběr témat, preferovány jsou láska, kult dámy a drobné epizody společenského života, dále antická a idylická témata. [...] Oblíbeny jsou perifráze, metafory, přirovnání atd., vedoucí však k vnější dekorativnosti a rétorické deklamativnosti“" (IBID.: 291-292). 
nu Pan Vyšínský (1861): „Ten jeho byt měl oddělení dvoje: / Zde Músa vládla svými zákony, / Tam opět síní šlo se do pokoje, / Jenž vedl přímo as $\mathrm{v}$ dva salony. / V nich elegance všecky dítky svoje / Pěstila v ladně vybroušeném vkusu, / Jak by to salon Francouzů či Rusů, / Kde haute volée se schází zívat nudně, / Pak pozdravit a pobavit se trudně; / Kde v bílých rukavičkách, v černém fraku / Se pije thé a... dřímá bez rozpakü“ (PFLEGER-MORAVSKÝ 1858: 19). Jan Pravoslav Koubek (1805-1854) dále poukazoval na amorální chování salonní společnosti: „[...] přemnoho [...] kousků, / kterých žádá dvornost velkopanská, / skoky, kadrily a menuety, / klevety a jiné etikety, / jež vynašla moda nadsekvanská, / které v každém lepším salonu, / náležely druhdy k bontonu [...]“ (KOUBEK 1857: 34). Od přelomu sedmdesátých a osmdesátých let 19. století byl salon v českém prostředí sice populární, avšak i tak byl vnímán jako místo společenských setkání a zábav, nikoli jako „instituce“ s filozofií umění života (HEMELÍKOVÁ 1999: 158). Lze tedy konstatovat, že český salon nikdy nedosáhl podoby a funkce, kterou měl ve Francii a Německu. Jiří Rak a Vít Vlnas v tomto směru použili výstižný pojem „česká hra na salon“ (RAK-VLNAS 1999).

I přes dobové výhrady se v českých beletristických časopisech od sedmdesátých let opakovaně objevovala próza se salonní tematikou. Mezi tyto časopisy patřil i Lumír, který byl řazen k periodikům s prestižní tendencí. Mezi autory, kteří debutovali salonní prózou již v sedmdesátých letech, byl i Jan Lier. V roce 1878 byla v časopise Lumír otištěna Lierova novela Graciella, ve které byl líčen osud hlavního hrdiny Stanislava, charakterizovaného jako tak zvaného lva salonu: ${ }^{6}$ „Stanislav chodil do dobrých domů jsa pravidelně nejlepšími výrobky počestného řemesla krejčovského ozdoben, maje na bílé modelové své hlavě vzorně upravenou i dobře pomadisovanou frisuru a na útlých rukou čisté glazé. Mluvil z ticha a po německu, znal jméno i vlastnosti každé módní látky, tajnosti pana X., poměry pana Y., den i rok narození všech princesek a jména všech koní i psů, kteří se kdykoli a kdekoli vyznamenali. Líbil se. [...] Avšak tatínkové si pojednou nechali záležeti na tom, aby se Stanislavovi zprotivili a dobře vychované dcerušky staly se chladnými a rozpačitými. Stanislav byl uražen. Rozhněval se posléze nemilosrdně na beau monde, zavřel album svých lásek do poslední přihrádky svého stolku a šel se pomstit na kráskách ku kráskám nerozpačitým“ (LIER 1878: 534-535).

6) Vedle ideálu české dámy (kultivované, elegantní, zároveň cudné) je v salonní próze frekventovaným typem mužské postavy právě tzv. lev salonu. V českém literárním prostředí však postava vyvolávala spíše negativní konotace (svůdník, zahaleč apod.). Podobnou charakteristiku má i hlavní hrdina Stanislav v Lierově novele, který je ale napraven čistou láskou. V české salonní próze často docházelo k projekci galantního muže do typu lva salonů. Problematice se blíže věnovala Blanka Hemelíková v příspěvku pro plzeňský sborník (HEMELÍKOVÁ 1999). 
Stanislav začal hýřit, až ztratil veškerou úctu k ženám. Znuděný životem odjel do Itálie, kde při kratochvilném cestování potkal dívku Graciellu, která ho změnila. Popis dívčí krásy korespondoval s hlavními znaky parnasistní literatury, pro niž je typický zejména důraz na vzácné drahokamy či květinový ornament: „Štíhlá jako palma, svižná jako kotě, s obličejem zšlechtilých rysů, pletí do zlatohněda opálenou, očima jak uhel černýma a jak opál fascinujícíma, rovným tupým nosíkem, rty purpurovými, kypícími, hedvábným, v bujných kučerách zpod koketně uvázaného šarlatového šátku se deroucím vlasem - tak stála před ním [...]“ (IBID.: 551). „[...] Milostná byla jako růže v rozkvětu, ryzá jako zlato, žhoucí jako paprsek toho slunce, pod nímž z bídy vypučela“ (IBID.: 553). Zamilovaný Stanislav „vysvobodil“ dívku z prostředí chudiny a vrátil se s ní po čase domů (po řádném vychování dle společenských zásad). Literární kritik František Kvapil (1855-1925) kladně reagoval na Lierovu prózu v časopise Květy a poukazoval na inspirační vliv francouzské konvenční literatury: ${ }^{7}$ „V Grazielle nám předveden typ velkoměstského hejska, který se nudí a jehož všecky požitky života už dávno omrzely. Podle francouzského receptu před úplným morálním úpadkem zachrániti ho může toliko líbezný, čistý zjev dívky. Z pouhé salonní loutky vyklove se znenáhla celý a hotový muž, který neštítí se práce a v ní nalezne lék pro všecky nudy dřivější [...]" (KVAPIL 1886: 120-121).

O rok později vyšlo v časopise Lumír hned několik Lierových próz se salonní tematikou. Humoreska Lásky bol svým názvem odkazovala k romantickému námětu, avšak s ironickým líčením milostných nesnází hlavního hrdiny Zobáčka. Ten, zamilován do sousedky slečny Míny, pravidelně navštěvoval rodinný společenský salon a choval se $\mathrm{k}$ dívce dle dobového očekávání patřičně galantně, i když s kapkou nervozity a nejistoty: „Zobáček navštěvoval slečnu Mínu, byl k ní nejpozornějším kavalírem, mořil se kvưli ní nedvornými a přenesrozumitelnými obraty řečnickými, chodil za ní jako lokaj, ždímal před ní neúnavně klobouk, snášel trpělivě každé čtveráctví a držel jí posléze i bavlnu při motání. Když konečně vyskytnul se nějaký tichý, osamělý kout, kolem něhož byly samé zavřené dveře a v němž stála Mínka s cudně sklopenýma očima, ruměným nádechem na lících a nyvě pootevřenými, chvějícími se rtíky, zástěrku cumlajíc a jediné zajímavé slůvko s přídavkem nějaké té hubičky očekávajíc“ (LIER 1879a: 6-7). Zápletkou humoresky byl omyl, kdy si Zobáček myslel, že ho Mína zradila a zasnoubila se $\mathrm{s}$ jiným mužem. Byl z toho neštastný a chřadl. Jeho přítel však

7) Možným inspiračním vzorem pro Lierovu novelu mohl být román Graziella (1852, v českém překladu 1872) francouzského spisovatele Alphonse de Lamartine (1790-1869). V románu byl líčen př́iběh mladého muže, který se na cestě po Itálii zamiloval do krásné dívky Gracielly, vnučky rybáře. Dívka však po nuceném odloučení zemřela. 
na nedorozumění přišel, a nakonec próza skončila št́astně sňatkem Zobáčka s Mínou. Humoreska Lásky bol byla v dobových kritikách považována za „obrázek zdařilý, ač prostinký“ (SOBOTKA 1882: 587) ${ }^{8}$, což bylo zapřičiněno zejména komicky pojmenovanou hlavní mužskou postavou a jeho až směšným chováním v př́ípadě nezdaru u své vyvolené.

V další povídce Šafránové šaty Lier tematizoval motiv nuceného sňatku. Prvky salónnosti v této povídce lze spatřit ve společnosti, která si libovala v plesových zábavách. Hlavní hrdinka Klára se zamilovala do rodinného přítele Peška, rodiče ji však nutili do sňatku s bohatším mužem panem Macákem (charakterizován opět jako lev, švarný junák a místním slečnám vítaný společník; LIER 1879: 59). Výjimečnost Klářiny krásy symbolizovalo hned několik motivů: anděl, nebeské hvězdy a růže: „Pešek zůstal státi oslněn u dveří spatřiv před sebou v růžových obláčcích stříbrem jako hvězdičkami protkaného tarlatánu se vznášejícího andílka, smavého, radostí záŕícího [...] Pan Kalous zahlédnul v zrcadle růžemi kvetoucí tváře a zářivé oči své dcery“ (LIER 1879b: 60). Klára domluvený sňatek odmítla, symbolem jejího vzdoru bylo obarvení bílých šatů šafránem. Lierova próza ústí v tragický konec, jelikož dívka neštěstím onemocněla a zemřela.

V novele Vlasta ${ }^{9}$ je líčen vztah mezi studentem Rosou a mladou dívkou Vlastou. Její rodina myslí na sňatek s baronem, proto je Rosa coby nápadník dcery odmítnut. V novele byl popsán dobový styl české salonní společnosti, avšak Jan Lier zde narážel na paradoxní podoby českého měštanského salonu, které neodpovídaly zahraničnímu vzoru: ${ }^{10}$ „Byl tam lustr, který nikdy nesvítil, pohovky, jež nikdo neobtěžoval, skvostné hodiny [...] pro samé dřevěné a skleněné rarity nebylo tu ke hnutí. Pan Bydeskuthy předpokládal zcela správně, že tomuto museu říkají u Hladkých ,salon' a vyčkával, až Oromek a ostatní společnost do salonu se vměstnala, uklonil se švihácky panu Hladkému a choti“ (LIER 1879c: 482). Rosa je zhrzen a ze vzdoru si vezme baronovu sestru Luczu. Kontrastním prvkem $\mathrm{k}$ měštanskému životu působí právě prostředí šlechty (společnost hovořící francouzsky, oddávající se kratochvilným zábavám, plesům a honům). Avšak manželství Rosy a Luczy není štastné. Lucza nakonec tragicky umírá při honu. S Vlastou se Rosa opět setkává po letech, kdy už je váženým profesorem. Vlasta

8) Próza Lásky bol byla přeložena do němčiny Edmundem Grünem a vyšla v roce 1890 v časopise Politik, dále byla otištěna v Slavische Bibliothek - Aus tschechischer Prosa v Lipsku roku 1893.

9) Do polštiny přeložil Hugo Wroblewski pod titulem Slawomira a vyšla ve varšavském Tygodniku illustrowaném roku 1884.

10) Na problém podoby českých salonů reagoval i Jan Neruda (1834-1891) v článku Společenský život, který není, a české salony, které také nejsou otištěném v Národních listech. V článku si Neruda „posteskl“ nad neexistencí českých salonů (NERUDA 1956: 559-561). Kritiky směřovaly k absenci vhodných témat ke konverzaci a připomínaly limity českého jazyka v diskuzi nad problémy politiky, filozofie, vědy a umění. 
je v české společnosti známa jako vzdělaná dáma, básnířka a národní buditelka. Rosa si uvědomil své „staré“ city.

Tato novela byla mimo jiné prodchnuta vlasteneckou otázkou žen a zejména problematikou jejich práv: „Žena jest a má býti v lidské společnosti pramenem života - nejen tělesného - v první řadě duševního a mravného; žena má býti elementem povzbuzujícím, unášejícím a udržujícím. [...] My ženy voláme po lidských právech - dobud'me si jich plněním svých povinností k národu, očištění sebe a povznešením se z nízkého otročení prostým fyzickým požadavkům životním. [...] Sestry! Vzhůru! My vládneme u kolébky a u krbu, my zmůžeme vše a vlejeme do žil národa svého nezdolnou sílu, stvoříme jeho velikost a slávu. Ještě jednou pravím vám družky: Bez žen jest každý národ i český národ ztracen!“ (LIER 1879c: 553). Tento vzor ženy, která měla být hrda na lásku k vlasti, nebyl v literatuře 19. století však ničím novým. Podobnou ideu ženy vlastenky hlásal například Josef Kajetán Tyl (1808-1856) již ve čtyřicátých letech 19. století. ${ }^{11}$ Avšak v Lierově podání působí líčení žen-vlastenek jako ironické gesto. Apely, které v Tylově snaze korespondovaly s intencemi požadavků vlasteneckého romantismu, se stávaly na konci sedmdesátých let 19. století snadno zesměšnitelným klišé. S tím souvisel i závěr samotné Lierovy prózy, ve kterém Rosa prozřel a odhalil manželčino plané vlastenčení, jelikož Vlastě posléze záleželo jen na udržení společenského postavení jejich rodiny.

V roce 1880 v Lumíru vyšla arabeska Rokoko. Ferdinad Schulz (1835-1905) arabesku považoval za skutečnou ozdobu novověké české novelistiky, která vykazovala nejjasnější znaky salonní prózy. Příběh byl zasazen do šlechtického prostředí a popisoval přepychový život šlechty, avšak i zhýralé šlechtické charaktery: „Kdežto přitažlivý pól šlechtické společnosti nechtěl se nikterak spustiti jeho kapsy, narážel pán z Cedersteina bez ustání svou přímostí a nevykvašenou modrokrevností na pól odpudivý, rozmrzen tím až do té duše umínil si pán z Cedersteina, že usídlí se na venkov, oddá se v zátiší pilnému studiu svých povinností rytířských a pojav za chot' urozenou dívku, objeví se teprvé se svými dcerami a syny na teatrum stavovském. [...] Pořídil sobě panství v severních Čechách, dostal k němu sešlý zámek rokokový s pustou francouzskou zahradou“ (LIER 1880: 147). Šlechtic, s nově koupeným titulem, ${ }^{12}$ potkal při procházce

11) Josef Kajetán Tyl významně přispěl k reflexi postavení českých žen ve společnosti. Byl si vědom, že do buditelských snah je potřeba zapojit právě ženy, vychovávatelky budoucí generace „vlastenců“. Psal články přímo pro ženy, snažil se v nich probouzet lásku k českému jazyku, k vlasti. Zejména ve svých dramatických kusech vytvářel obraz ideální ženy-vlastenky. Blíže viz CHVÁLOVÁ 2012.

12) Obdobný satirický námět módního dohledávání rodokmenu a kupování šlechtických přídomků zpracoval Jan Lier ve veselohře Flora (premiéra 19. 2. 1880 na scéně Prozatímního divadla). 
po panství nádhernou ženu lady Elizu, schovanku místního barona Kozlanského, kterou byl na první pohled okouzlen: „Jako drahokam na černé podušce aksamítové, tak vyniklo $\mathrm{z}$ temného pozadí oratoria překrásné ženské poprsí v jasném glorifikujícím světle: půvabná hlava s plavým, přebohatým, do stříbra hrajícím vlasem, upraveným ve vysoké toupé, obličej růžový, pár velikých mandlovitých očí pod vysokým, hrdě klenutým obočím, jemný, lehýnce zahnutý nosíček, tváře a brada s důlky“ (IBID.).

V arabesce jsou hned dvě scény milostných „dostaveníček“ - první milostná scéna s houpačkou, tradiční kratochvilnou zábavou šlechty, jejíž popis opět odkazuje k tradici parnasistní poetiky: „Stranou, asi dvacet kroků od něho lítala v podobě mušle, pozlacená, perletí a bílou kostí vykládaná, v pozadí stojící sluha držel šňưru $\mathrm{k}$ houpačce připevněnou a dával mušli na povel stále rychlejší a rychlejší let. A v mušli vznášela se lady Eliza rozdováděná, planoucí, oslňující! [...] Uhřátá, s dmoucími se ňadry a pohrávajíc vějířem procházela se chvilku, pohlížejíc na neznámého zvědavě [...]“" (IBID.: 161). Druhá milostná scéna je na jezeře, kdy pár osamocen plul na lod'ce. Lady Eliza odmítla city hlavního hrdiny, jelikož byla milenkou barona Kozlanského a zároveň byla vdaná. Šlechtic vystřízlivěl a poznal opravdový charakter šlechtičen. Arabeska je zakončena ironickým koncem a poučením: „Okénko vozu slétlo a v něm se objevila nejprve bílá útlá ručinka, pak smavá tvář s párem zářicích očí. ,Slibte mi, že nebudete bláhovým panem z Cedersteina. Musila bych se vám vysmáti, jako každé opravdové lásce. Vive la joie - jako v zlaté době rokokové!' [...] Pán z Cedersteina s těžkou omámenou hlavou si ulehnuv upadl v těžký sen, plný pudrovaných paruk, šarlatových střevíčků, graciósních, lehkovážných záletnic a tlustých porcelánových mandarinů. Procitnuv, vzal si všechno rokoko vidiosynkratickou ošklivost, pojal za chot' dceru svého sedláka a vystavil v Sidneyi nejkrásnější českou řípu cukrovku“ (IBID.: 163). Z prózy vyplývá zjevná satira na nově nobilizovanou aristokracii, která se snažila inspirovat životem šlechty a zároveň se sentimentálně zhlížela v době rokoka, aniž by si uvědomovala, že $\mathrm{k}$ rokoku patřila též galantní a předstíraná láska.

I když předmětem studie jsou Lierovy salonní prózy ze sedmdesátých let 19. století, i v osmdesátých letech pokračoval Jan Lier v časopiseckém publikování salonních próz, ve kterých postupem času nalezl svůj literární výraz. V časopise Lumír vyšly např́klad arabeska Hop-lá (1881), prózy Eva (1881), Trojí panstvo (1882), novely Klín klínem (1883) a Vojtěcha Rývy nástupce (1885). V novele Vojtěcha Rývy nástupce lze shledat Lierův pokus o pražský román z vyšší společnosti, v němž dokonce existuje fiktivní pražský „preciosní“ salon. 
Na přelomu osmdesátých a devadesátých let se však již Lierovy novely stávaly jistým anachronismem (JEŽKOVÁ 2014: 49) a cesta k postupnému zapomnění Jana Liera coby salonního autora tak byla zahájena.

\section{Literárněkritické ohlasy v dobových časopisech}

Jan Lier vstoupil do literatury pod záštitou Jana Nerudy (1834-1891), ${ }^{13}$ jehož vliv byl patrný $v$ tendenci žánrového realismu, např́klad akcentací tématu nuceného sňatku. V Lierově tvorbě bylo zastoupeno i nerudovské téma životní deziluze (FRÁNEK 2015: 322). Realistický detail koexistoval v kontrastu s milostným pojetím a výrazivem, „s náměty fabulovanými s těkavou obrazotvorností, nezastavující se před nejkřiklavějšími paradoxy" (JEŽKOVÁ 2014: 48-49). Vlivem parnasistní literatury se Lier sbližoval se skupinou autorů kolem časopisu Lumir (zejména tendencí po efektním ději, zobrazení života vyšší společenské vrstvy). Jan Lier se evidentně snažil být salonním autorem jak námětem próz, tak vybroušenou salonní mluvou postav. Nejožehavější dobová témata „odbavoval s touž graciesností, ale i s touž nezávaznou hravostí a třpytnou salonní lehkostí konversační, která někdy přiliš bila do očí a pro niž snadno býval přezírán i jeho zápal reformátorský, stejně opravdový jako vznětlivý“ (SEZIMA 1918-1920: 26).

Lierova próza oscilovala na hranici parnasistní literatury s konvenčně zábavnou literaturou, která byla určena pro vzdělané čtenáře (čtenářky) středních vrstev. Efektními dějovými zápletkami a snahou o zobrazení prostředí vyšších vrstev se Lier dostával do blízkosti konvenční dobové četby salonních novel a románů. Za salonního autora byl označován mnoha literárními kritiky. Například Bohuslav Čermák (1846-1899) oceňoval snahy zpracovávat témata společenských salonů: „Vážíme si jej proto, že on první počal pěstiti četbu rozvinutějšímu nyní životu národnímu přiměřenou v těch kruzích, které své choutky po pikantním a hladším žánru ukájely z ciziny. Nelze tajiti, že máme již rudimenta salonů měštanských i panských, jež uměním lze národu tužeji přivinouti“ (ČERMÁK 1886-1887: 44). Jan Neruda zároveň zdůrazňoval Lierův pozorovatelský cit pro detail, který byl charakteristický pro poetiku realismu: „Jeho povídky jsou přebohaty na psychologické, řekněme lidské perspektivy, jeho slovní kresby jsou naprosto určity a jeho dialogy jsou bohaté na drobný detail lidský. [...] Ale necht'

13) Jan Neruda z rukopisů fejetonů Jana Liera, které mu byly roku 1877 zaslány, poznal v autorovi zjevný talent. Následně byly fejetony otištěny v Národních listech. 
krouží jen nad tím revírem svým nejvlastnějším nebo zašvihne v kteroukoliv jinou stranu literární, vždy jest při něm síla a elegance: Lier je náš vypravovatel vskutku salonní" (NERUDA 1952: 208).

Dějové zápletky Lierových próz jsou převážně milostné, čtenářsky přitažlivé. Sentimentální pohled byl podpořen parnasistními prvky (dekorativností a květinovou ornamentálností), které jsou v protikladu s Lierovým smyslem pro detail. Za realistického autora považoval Jana Liera i František Vykoukal, který poukazoval na autorův um spojovat realismus právě s romantičnem: „Látkami většiny svých prací chýlí se Lier k realismu, ve kterém se mu také nejlépe daří, tu a tam však odbočuje odtud velmi znatelně k romantismu, jemuž místy výhradně se oddává. Osnovou a technikou svou čelí více k romantismu než realismu, ač ani tu nelze stanoviti obecného pravidla pro veškerou tvorbu jeho z doby, o níž tuto mluvíme. Formu se stránky slovesné má tou měrou v moci, že přizpůsobuje řeč ku povaze osob i časů, jichž se týče, a že, maje zálibu ve slohu bleskotném, sytém a zářivém, hravě vyhledává vše, čím by této zálibě vyhověl“ (VYKOUKAL 1887: 269). Parnasistní tendence byly zřejmé i v rokokových prvcích. ${ }^{14}$ Pro Lierovu salonní prózu byla charakteristická snaha pro skloubení parnasistních motivů s reáliemi českých zemí. Pomyslný parnasistní ideál „ک̌íše krásy“ byl v próze konfrontován s přízemním materialismem českého prostředí (FRÁNEK 2015: 340). Dekorativní a malebné popisy, tendence prolamovat tabuizovaná témata sice přibližovaly Liera $\mathrm{k}$ francouzské konvenční próze, $\mathrm{v}$ českém prostředí však působily provokativně. To se týkalo i erotických prvků s důrazem na ženskou krásu (popisy boků, ňader apod.). Ferdinand Strejček (1878-1963) poukazoval na fakt, že Lierova próza vykazovala větší míru erotiky, než na jakou byla dosavadní česká próza zvyklá (STREJČEK 1915: s. 73). Nicméně i přesto erotické scény podléhaly dobovému konvenčnímu pohledu a vyústovaly v smyslně sentimentální „cukrování“ (SEZIMA 1918-1920: 26).

V letech 1883-1886 vyšly dvě dvousvazkové knižní sbírky Lierových próz pod názvem Novely, ${ }^{15}$ do kterých byly zařazeny prózy časopisecky vydávané

14) Rokokové prvky byly dominantní i v pracích jiných parnasistních autorů, např́klad v poezii Jaroslava Vrchlického (1853-1912) či Bohdana Kaminského (1859-1929). Z prózy uved'me povídku Julia Zeyera (1841-1901) Rokoko.

15) V roce 1883 vyšel první díl Novel. V prvním svazku byly zařazeny prózy Lásky bol (Lumír, 1879), Na téže koleji (Lumír, 1880), Model (Květy, 1879), U profilu 23 (Květy, 1880), Tré večerů (Koleda, 1877), Mefisto páté sekce (Květy, 1880); ve druhém svazku Deset minut (Lumír, 1879), Lipnická zábava (Lumír, 1879 pod názvem Šafránové šaty), Vlasta (Lumír, 1879) a Archeologická novelka (Lumír, 1880 pod názvem Na věži). V roce 1886 byly v prvním svazku prvního dílu zařazeny prózy Ze všedního světa (Slavia, 1878 pod názvem Romaneto bez lásky), Únos Sabinky (Květy, 1882), Špatní lidé (Lumír, 1879), Mlles d’Agacerie (Květy, 1883), Odkazy (Světozor, 1880), v druhém svazku druhého dílu próza Hop-lá! (Lumír, 1881), Rokokové dobrodružství (Lumír, 1880 pod názvem Rokoko), Dítě s kozlíka (Lumír, 1882), Za vinu utrpenou (Květy, 1881 pod názvem Stín minulosti). 
průběhu sedmdesátých a osmdesátých let. Obě vydání byla publikována v Ottově knižnici Salonní bibliotéky. Největší zastoupení měly zejména novely se železniční tematikou. Zařazeny byly ale i salonní prózy z časopisu Lumír: Lásky bol, Vlasta, Šafránové šaty (pod názvem Lipnická zábava) či Rokoko (pod názvem Rokokové dobrodružství). V roce 1886 vyšla další kniha Lierových próz Arabesky a novely, ${ }^{16}$ ve které byla otištěna novela Graziella. František Kvapil (1855-1925) reagoval na Lierovy salonní prózy kladně, oceňoval Lieorovo realistické oko pro popis života střední vrstvy a salonního života s elegancí a vkusem: „V Lierovi nám vyrostl novellista nevšední virtuosity. Elegance a vkus jsou jeho předním znakem a na parketách povídky ze souvěkého života společenského ne každý s takou jistotou pohybovati se dovede. Lier má vnímavý zrak pro jeho zjevy každodenní i zvláštní a bystře, psychologicky je analyzuje. [...] Lier jest salonní náš spisovatel v lepším slova významu, výtečný stylista, poutá lahodou svého vypravování a každý jemný záchvěv citový, každou nuanci myšlenkovou smí zachytiti a ozářiti případným světlem [...]“ (KVAPIL 1886: 120). K podstatě Lierovy tvorby se vyjadřoval i Ferdinand Schulz (1835-1905), který viděl kvalitu próz nejen v zábavné funkci, nýbrž i v nutnosti čtenářské součinnosti: „Pro pouhou chvilkovou zábavu, pro ubíjení zbytečného času čtením Lier nikdy nepíše, jeho novely vyžadují stálého přemýšlení, bedlivého stopování vypravovací niti, duchovní součinnosti čtenářovy. Vzrušující smysl a obraznost, přinášejí stále nová a nová překvapení a nepozorovatelným, vhodným, v pravdě uměleckým obratem v situaci nebo $v$ náladě jednotlivé osoby přivodí ukončení, vymykající se obyčejnému výpočtu, a přece naskrze přirozené, a ne li vždy uspokojující a příjemné, zajisté vždy tak důsledné a přirozené, že proti němu není lze ničeho namítati“ (SCHULZ 1885-1886: 766-767).

$\mathrm{Z}$ výše uvedených důvodů byly Lierovy Novely u čtenářského publika v oblíbenosti. Anonymní recenzent $\mathrm{v}$ časopise Zvon poukazoval na novost Lierovy prozaické tvorby, která čtenáře velmi „lákala“: „Práce jeho rázem zaujaly pozornost čtoucích kruhů: přinášely něco nového; nového ovzduším, z něhož čerpány byly, i svěží břitkou úsečnou formou, světélkující vtipem a ironií začasté až mefistofelskou“"(ANONYM 1903: 71). František Dlouhý (1852-1912) v Literárních listech oslavoval záměr knižného vydání próz autora, který si v krátké době vydobyl jasné úspěchy u dobového čtenářstva: „Autor novel před námi ležících získal sobě v krátké době jména tak zvučného a obliby veškerého čtenářstva českého tak velké, že potěšeni byli jsme zprávou o souborném vydání jeho prací

16) V knize vyšly zároveň prózy Jezule (Vánoční album, 1882), Vašnostinka (Lumír, 1883), Povídka s mrzutým koncem (Květy, 1881), Eva (Lumír, 1881), Housle (Velký pražský kalendář, 1881). 
belletristických dosud po různých časopisech roztroušených“ (DLOUHÝ 1883: 39-40). Josef Patočka (1869-1952) viděl Lierův úspěch v „dychtivosti“ dobových čtenářu zejména po salonním tématu, které chybělo dobové společnosti v mnoha sférách: „Lier, on byl Mefisto novelistické sekce české literatury, její novelista par excellence, dekorovaný titulem, [...] čtenářstvo s dychtivostí viselo na jeho rtech, když tvořil na papíře všecko, co nám scházelo ve skutečnosti: české bohatství, českou nádheru, český salon, české umění, vítězství české práce v cizině. [...] Také jeho jemný smysl pro krásu a luxus, jeho znalectví umění, jeho líčení jihu a cizozemí opojovala“ (PATOČKA 1901: 44-45). Naopak Svatopluk Čech (1846-1908) byl toho názoru, že za úspěšností Lierových próz bylo nejen zdařilé vypravování, ale také kombinace humoru a satiry: „Živé a svižné vypravování, které tě rázem strhne ve své hravé vlně a unáší tě lehce proudem napínavého děje - při té hravosti a lehkosti i hloubka, síla a vzlet, jež tě dovedou rozechvět a uchvátit - delikátní kresba a svěží barvy líčení - výrazná, avšak při tom vždy umělecky ladná charakteristika - jemný nádech humoru a satiry, tendence vystupující ochotně, ale nikoli dotíravě, květnatá, uhlazená mluva a kolem všeho libý opar skutečné poesie - tot' asi ve hlavních rysech literární obraz našeho autora, tedy zajisté obraz, jaký si rázem dobývá srdcí čtenářstva“" (ČECH 1883: 117).

I přes dobovou čtenářskou oblíbenost zapadl spisovatel Jan Lier postupem času mezi méně známé salonní autory, kteří postavili svou prozaickou tvorbu na tendenčním milostném námětu z prostředí salonů. Aleš Haman pomíjivost obliby Lierových prací u dobového čtenářstva shledal v postupném posunu na periferii literárního vkusu (v oblíbenou duševní „stravu“ maloměštáckého čtenáře). Právě popularita byla Lierovi osudná, nebot' autora vedla k opakování osvědčených motivů a látek, jejichž účinkem si byl předem jist (HAMAN 1961: 69). Trnem v oku byl Jan Lier konzervativním vlastenčícím kritikům za nadužívání cizích slov či celých francouzských bonmotů, ale i náměty a prostředí společenských salonů. Do této kritiky spadal i samotný časopis Lumír. Možná i to mělo svůj podíl na poklesu popularity Lierovy salonní tvorby v prvních desetiletích 20. století. Přes zjevně silné „anti-salonní“ hlasy z řad literárních kritiků se tak Jan Lier možná stal neprávem zapomínaným a nedoceňovaným romanopiscem (X 1922: 603). 


\section{Závěr}

Lierova salonní próza publikovaná v časopise Lumír na konci sedmdesátých let 19. století vykazovala jednak znaky populární literatury, jednak prózy s vyššími uměleckými ambicemi. Salonní téma bylo zastoupeno popisem provozování společenských salonů s kratochvilnou zábavou (tanec, hudba, zpěv), ale i prostředím vyšší společnosti. Volba příběhů ze společenského života se sentimentálním podtextem (romantická „dostaveníčka“, láska vyústěná v tragický konec) znamenaly orientaci do širších čtenářských řad, zejména pak mezi ženské čtenářky. Zároveň však lze v analyzovaných prózách nalézt prvky vyžadující vyšší čtenářské kompetence. To se týkalo například parnasistních prvků (dekorativnost, ornamentálnost), tendence k exkluzivnosti či pronikání francouzských slov.

Kvůli prolínání zjevných prvků z rovin „nízké“ a „vysoké“ literatury se nabízí možnost uvažovat o salonní próze ve vztahu ke střední literární roviněi7 a pracovat $s$ tzv. triadickým modelem literatury ${ }^{18}$, ze kterého vycházel v úvahách o vnitřní diferenciaci literatury např́iklad Umberto Eco. S každou rovinou tři odlišných stylů (nízkého, středního, vysokého) souvisela i typická tematika a motivy. Dle Dagmar Mocné je nutné na každou rovinu nahlížet jako na legitimní součást literárního sytému, $v$ němž má daná rovina svou specifickou funkci („z roviny vysoké vyvěrají tvưrčí výboje, rovina střední tyto výboje rozšiřuje $\mathrm{v}$ prostoru a stabilizuje $\mathrm{v}$ čase, rovina nízká je elementárním rezervoárem čtenářství;; MOCNÁ 2014: 83). Podle Umberta Eca šlo dílům spadajícím do této roviny o „stimulování různých zkušeností souvisejících s celou řadou dojmů estetických, k čemuž si z umění ve funkci objevitelské vypůjčuje postupy a stylegmata, aniž by to, co si vypůjčilo, proměnilo v banalitu, ale naopak to zařazuje do smíšeného kontextu, který by rád jednak stimuloval efekty únikové a lichotivé, a jednak podněcoval ne zcela nehodnotné interpretativní zážitky, a to proto, aby v této své dvojí funkci mohlo získat určitou strukturální nezbytnost

17) V současných odborných pracích je používán i termín literární midcult, pro něhož je příznačná „snaha zúročit literární i obecný kulturní rozhled tvůrce, jenž se projevuje modifikací či aktualizací témat rezonujících ve světové literatuře [...] a snahou reagovat na soudobé společenské a kulturní klima“ (VRAJOVÁ 2017: 197). Této definici odpovídá i samotný modelový čtenář, jehož čtenářská kompetence „většinou disponuje k tomu, aby mohl rozeznat (případně ocenit) odkazy na nejnovější literární podněty; zároveň ovšem očekává čtenářský zážitek, při němž mu bude nabídnuta hodnotová orientace v soudobém světě“ (IBID.: 197-198). Nicméně s pojmem literárního midcultu vyvstává zejména problematika sociologického př́istupu.

18) Triadický model literatury má své kořeny již v antické literatuře. Tento model se „odvolává se na teorii vysoké, střední a nízké kultury a zvláště na antickou rétorickou tradici tří stylových rovin, jež rozlišuje vznešený, střední a nízký styl (lat. stylus humilis, ,nízký“, mediocris nebo medium, ,střední, a gravis, doslova ,vážný, nebo sublime)“ (ŠIDÁK 2013: 203). 
a odvést často velice užitečnou práci“ (ECO 1995: 129). Eco definoval charakter literární produkce střední roviny jako smíšený se snahou čtenářské atraktivity (s využitím některých postupů nízké roviny) a stimulací hodnotných estetických prožitků. Podle této charakteristiky je tak možné o salonní próze hovořit jako o žánru střední literární roviny, ve které koresponduje romantické stigma s kombinací ironie, realistické otevřenosti a snahy po čtenářské exkluzivnosti námětů z prostředí vyšší společnosti.

Studie vznikla za finanční podpory specifického výzkumu na FF MU (MUNI/ A/1101/2020). Při práci na textu studie byly využity zdroje/služby výzkumné infrastruktury Česká literární bibliografie (kód ORJ: 90136).

\section{PRAMENY}

\section{ANONYM}

1879 „Literatura česká“, Světozor 13, č. 3, s. 34

1888a „Zpráva“, Hlídka literární 5, č. 6, s. 192-193

1888b „Zpráva“, Národní listy 28, č. 105, s. 2

1892 „Zpráva“, Národní listy 32, 1892, č. 334, s. 3-4

1903 „Týden“, Zvon 3, č. 5, s. 71-72

ČECH, Svatopluk (pseud. S)

1883 „Novelly Jana Liera“, Květy 5, č. 1, s. 117

ČERMÁK, Bohuslav

1886-1887 „Jan Lier. Novely. Knihy druhé díl 1“, Rozhledy literární 1, č. 2, s. 44-45

ČERVINKA, Vincenc

1912-1913 „Dvě šedesátá výročí“, Zlatá Praha 30, č. 8, s. 95

DLOUHÝ, František

1883 „Novelly Jana Liera“, Literární listy 4, č. 5, s. 39-40

1886 „Kritika“, Literární listy 7, č. 16-17, s. 260-262

DYK, Viktor

1916-1917 „Literatura“, Lumír 45, č. 8, s. 375-376

HÁLEK, Vítězslav

1912 „V př́rodě“, in Sebrané spisy IX (Praha: Nákladem Jana Laichtera), s. 275 
Pavlína Dušková

Salonní próza Jana Liera v časopise Lumír v letech 1878-1880

KOUBEK, Jan Pravoslav

1857 Sebrané spisy veršem i prózou (Praha: Karel Bellman)

KVAPIL, František

1886 „Rozhledy“, Květy 8, č. 1, s. 120-121

LAMARTINE, Alphonse de 1872 Graziella (Praha: Theodor Mourek)

LIER, Jan 1878 „Graciella“, Lumír 6, č. 34, s. 635-536; č. 35, s. 551-553; č. 36, s. 568-570

1879a „Lásky bol“, Lumír 7, č. 1, s. 6-9

$1879 b$ „Šafránové šaty“, Lumír 7, č. 4, s. 59-62

1879c „Vlasta“, Lumír 7, č. 31, 482-485; č. 32, 498-501; č. 33, 513-516; č. 34, 536-538; č. 35, 552-554;

č. 36, 567-570

1880 „Rokoko“, Lumír 8, č. 10, s. 146-149; č. 11, s. 161-163

1890 „Provolání. Vzdělanstvu českému“, Národní listy 30, č. 172, příloha s. 3

NERUDA, Jan

1952 „Jan Lier“, in Podobizny II. Spisy Jana Nerudy 30 (Praha: Československý spisovatel), s. 208-209

1956 „Společenský život, který není, a české salony, které také nejsou“, in Česká společnost II (Praha:

Československý spisovatel), s. 559-561

PATOČKA, Josef

1901 „Jan Lier. Klín klínem“, Obzor literární a umělecký 3, s. 44-45

PFLEGER-MORAVSKÝ, Gustav

1858 Pan Vyšínský (Praha: J. Pospíšil)

SABINA, Karel

1911 Na poušti (Praha: B. Kočí)

SEKANINA, František

1917 „Jan Lier“, Zvon 17, č. 37, s. 519-520

SEZIMA, Karel

1918-1920 „Z nové i starší novelistiky“, Lumír 47, č. 1, s. 23-28

SCHULZ, Ferdinand

1880 „Nové písemnictví“, Osvěta 10, č. 4, s. 345-346

1885-1886 „Literatura“, Zlatá Praha 3, č. 48, s. 766-767

SOBOTKA, P.

1882 „Rozmanitosti“, Světozor 16, č. 49, s. 587 
VYKOUKAL, František Vladimír

1887 „Nové písemnictví. Výpravná prosa“, Osvěta 17, 1887, č. 3, s. 268-272

$\mathrm{X}$.

1922 „Jan Lier. Narcissa“, Zvon 22, 1922, č. 43, s. 603

\section{LITERATURA}

ECO, Umberto

1995 Skeptikové a těšitelé (Praha: Svoboda)

FRÁNEK, Michal

2015 „Zeyer, Vrchlický, Lier: Česká próza v dotyku s parnasismem“, in HAMAN, Aleš - TUREČEK, Dalibor (eds.): Český a slovenský literární parnasismus: Synopticko-pulzační model kulturního jevu (Brno: Host), s. 293-341

GRIMM, František

1935 Lierové: rodopisná črta a seznam děl Jana Liera (Kutná Hora: Archeologický sbor Wocel)

HAMAN, Aleš

1961 „Zapomenutí žánroví realisté“, Česká literatura 9, č. 1, s. 69-71

2015 „Užití pojmu v dosavadní české tradici, motivace znovuzavedení“, in HAMAN, Aleš - TUREČEK, Dalibor (eds.): Český a slovenskýl literární parnasismus: Synopticko-pulzační model kulturního jevu (Brno: Host), s. 13-37

HEMELÍKOVÁ, Blanka 1999 „Projekce ideálu českého galantního muže do typu lva salonů a jeho obraz v české literatuře 19. století, in LORENZOVÁ, Helena - PETRASOVÁ, Tatána (eds.): Salony v české kultuře 19. století (Praha: Koniasch Latin Press), s. 155-160

HORSKÁ, Pavla

1999 „Český literární salon a salon v české literatuře“, in LORENZOVÁ, Helena - PETRASOVÁ, Tatána (eds.): Salony v české kulture 19. století (Praha: Koniasch Latin Press), s. 172-177

CHVÁLOVÁ, Lenka

2012 Žena v divadle Josefa Kajetána Tyla (Praha: Nakladatelství Kant)

JEŽKOVÁ, Petra

2014 Obležen národem dramatiků. Jan Lier (1852-1917) (Praha: Academia)

KOVÁŘOVÁ, Zdena

1984 „Preciózní literatura“, in VLAŠÍN, Štěpán (ed.): Slovník literární teorie (Praha: Československý spisovatel), s. 291-292. 
Pavlína Dušková

Salonní próza Jana Liera v časopise Lumír v letech 1878-1880

1984 „Salonní literatura“, in VLAŠín, Štěpán (ed.): Slovník literární teorie (Praha: Československý spisovatel), s. 334-335.

LORENZOVÁ, Helena - PETRASOVÁ, Tatána (eds.)

1999 Salony v české kulture 19. století (Praha: Koniasch Latin Press)

MACURA, Vladimír

2015 „Sen o salonu“, in Znamení zrodu a české sny (Praha: Nakladatelství Academia), s. 507-514

MOCNÁ, Dagmar

1999 „Salonní novely Karolíny Světle“", in LORENZOVÁ, Helena - PETRASOVÁ, Tatána (eds.): Salony $v$ české kultuře 19. století (Praha: Koniasch Latin Press), s. 147-154

2014 „Editorial“, Bohemica Olomucensia 6, č. 2, s. 79-84

2014 „Šest povídek o starém mládenci: Nerudova próza v rozpětí mezi literárními rovinami“, Bohemica Olomucensia 6, č. 2, s. 87-125

RAK, Jiří a VLNAS, Vít

1999 „Česká hra na salon“, in LORENZOVÁ, Helena - PETRASOVÁ, Tatána (eds.): Salony v české kultuře 19. století (Praha: Koniasch Latin Press), s. 223-234.

SOCHOROVÁ, Ludmila

1999 „Ideál české dámy“, in LORENZOVÁ, Helena - PETRASOVÁ, Tatána (eds.): Salony v české kultuře 19. století (Praha: Koniasch Latin Press), s. 178-186

STREJČEK, Ferdinand

1915 Lumírovci a jejich boje kolem roku 1880 (Praha: Česká akademie císaře Františka pro vědy, slovesnost a umění)

ŠIDÁK, Pavel

2013 Úvod do studia genologie (Praha: Akropolis)

ŠVEHLA, Jaroslav

2002 Jan Otto: kus historie české knihy (Jinočany: H\&H)

TUREČEK, Dalibor

1999 „Salon jako dramatický prostor“, in LORENZOVÁ, Helena - PETRASOVÁ, Tatána (eds.): Salony $v$ české kultuře 19. století (Praha: Koniasch Latin Press), s. 161-171

VRAJOVÁ, Jana

2014 „Přes middlebrow k midcultu. K historii konstituování termínu midcult“, Bohemica Olomucensia 6, č. 2, s. 139-146

2017 Uminěnkyně dobra Sofie Podlipská. Kapitola z dějin literárního midcultu 19. století (Praha: Akropolis) 
Mgr. Pavlína Dušková, 413317@mail.muni.cz, Ústav české literatury, Filozofická fakulta Masarykovy univerzity, Brno, Česká republika / Department of Czech Literature, Faculty of Arts, Masaryk University, Brno, Czech Republic 